Chapter Title: A World Community of Neighbours in the Making Resource Cosmopolitics and Mongolia's 'Third Neighbour' Diplomacy

Chapter Author(s): Uradyn E. Bulag

Book Title: The Art of Neighbouring

Book Subtitle: Making Relations Across China's Borders

Book Editor(s): Martin Saxer, Juan Zhang

Published by: Amsterdam University Press. (2017)

Stable URL: http://www.jstor.org/stable/j.ctt1jd94h1.10

JSTOR is a not-for-profit service that helps scholars, researchers, and students discover, use, and build upon a wide range of content in a trusted digital archive. We use information technology and tools to increase productivity and facilitate new forms of scholarship. For more information about JSTOR, please contact support@jstor.org.

Your use of the JSTOR archive indicates your acceptance of the Terms \& Conditions of Use, available at http://about.jstor.org/terms

This book is licensed under a Creative Commons Attribution-NonCommercialNoDerivatives 4.0 International. To view a copy of this license, visit http://creativecommons.org/licenses/by-nc-nd/4.0/. 


\title{
5 A World Community of Neighbours in the Making
}

\author{
Resource Cosmopolitics and Mongolia's 'Third Neighbour' \\ Diplomacy
}

Uradyn E. Bulag*

\section{Introduction: Mongolia's Third Neighbour Policy}

The late 1980 s was a momentous period in world history, and like many countries in the world, Mongolia was caught up in it. ${ }^{1}$ The country's pro-democracy movement, which rose in momentum in the same period, was simultaneously an anti-Soviet colonial liberation movement, as it denounced Soviet exploitation, colonization and even genocide in the late 1930s. Meanwhile, the Sino-Soviet détente was accompanied by the Soviet withdrawal of troops from Mongolia (Radchenko 2012), a rapid waning of the Soviet power, and the eventual collapse of the Soviet Union in late 1991. Thereupon Mongolia lost its traditional guarantor of independence as much as it rejected it. What it meant for the new democracy was that it was left to face China alone, a historical nemesis, and a communist state that had just used its military power to crush its student movement in Beijing and the Tibetan rebellion in 1989. As Inner Mongols from China flooded into Mongolia, the sinicized demeanour and speech, perceived or real, of some of the visitors horrified the Mongols in Mongolia, serving as a mirror for the Mongols to see what a Chinese colonization might look like (Bulag 1998). They developed a profound sense of insecurity; Mongols were paranoid that an impoverished Russia might sell Mongolia to China, something called for by ultra-rightist nationalists such as Vladimir Zhirinovsky. The collapse of the Soviet Union and Russia's fall in fortune galvanized Mongolia to reshape its foreign policy as a matter of national survival.

In June 1990, a month after the Mongolian People's Republic amended its Constitution to legalize opposition parties and scheduled a multi-party

\footnotetext{
* My thanks to the editors for invitation to 'The Art of Neighbouring: Old Crossroads and New Connections along the PRC's Borders' they organized at Asia Research Institute, National University of Singapore.

1 Mongolia was known as the Mongolian People's Republic from 1924 to 1992.
} 
election, the United States sent its first residential ambassador, and on August 2, 1990, less than a month after the election, the US Secretary of State James A. Baker, III came to visit Mongolia and addressed the new Mongolian parliament to bolster this young democracy. He reportedly told the Mongolians to the effect that 'Mongolia has two good neighbours, but if needed a third, the US would be happy to be it' (Campi 2005: 48). The United States then led the way in supporting Mongolia's transition, rallying democratic countries to provide economic assistance (Addleton 2013).

The United States' neighbourly posture to Mongolia was, no doubt, designed to replace the collapsing Soviet Union, and help Mongolia to balance China's growing economic and political influence. As Munkh-Ochir Dorjjugder writes, 'A rhetorical gesture to support the nation's first move toward democracy [...], it meant more to Mongolians than to any American present at the speech. The idea, possibly quickly forgotten in Washington, was immediately picked up by the Mongolian elite' (Dorjjugder 2011). Although the Mongolians were deeply encouraged and inspired by James Baker's proposal, and began to seek 'third neighbours' among democratic and economically advanced nations, according to Alicia Campi, the US did not initially appear to be willing to be committed to its own promise:

As former Mongolian Minister of Foreign Affairs, L. Erdenechuluun wrote: 'To many Mongolian politicians and government officials, the US would appear as the savior of new Mongolia and "major pillar" of its national security'. However, at first, American officials dismissed the Third Neighbour concept as a non-starter, because they viewed Mongolia as a friendly, but minor nation wedged between significant American rivals, Russia and the PRC. (Campi 2010: 90).

The initial non-committal stance of the US was a reminder to Mongolia that the virtual non-territorial 'third neighbours' could never be a physical deterrent to any Chinese or Russian aggression. Thus, in the National Security Concept developed in 1994, Mongolia moved away from its classical approach of 'hard balancing' or relying on a friend against an enemy. It declared that Mongolia's foreign policy would be based on political realism, nonalignment, pursuit of national interest, and participation in international efforts to strengthen international peace and security. Responding to the changed geopolitical condition of Mongolia, and repositioning itself as a 'small state', Mongolia began to treat China and Russia as equal neighbours, hoping to keep them at equal distance while 
improving relations with them simultaneously. Formulated as neighbours, Mongolia no longer treats them as friend or enemy, so that Mongolia's new post-socialist foreign policy is officially not to antagonize either, still less both. Importantly, Mongolia revived the 1930s' idea of building a neutral state, as advanced by the Buryat Mongolian scholar Tseveen Jamtsarano. This is best manifested in the declaration of Mongolia's territory to be a 'nuclear-weapon-free zone' made by President P. Ochirbat to the General Assembly of the United Nations on September $25^{\text {th }}, 1992$. It was a solemn pledge that Mongolia would not take sides with either of its neighbours or allow its territory to be used against the other as happened in the $1960 \mathrm{~s}$ to the end of the 1980 os when Mongolia was a host to a number of Soviet military bases with nuclear weapons. ${ }^{2}$

After more than a decade of active experiment, Mongolia formally enshrined its Third Neighbour policy in the renewed National Security Concepts of Mongolia passed in June 2010. More than any other nations in the world, the concept of 'neighbour' has come to occupy the core in Mongolia's conceptualization of its place in the world. In this new policy, Mongolia pivots its national sovereignty not only on treating China and Russia as neighbours, keeping them at equal distance, but more importantly on the so-called 'third neighbours', a conglomeration of democracies plus a few select friendly non-democracies. These 'third neighbours', of which the US, the EU, and Japan being the most important, are all territorially non-contiguous with Mongolia, either by land or by sea.

This chapter is an attempt to understand Mongolia's Third Neighbour approach as its new art of neighbouring. Mongolia's new foreign policy has been primarily for defensive purpose, to use the Third Neighbours to offset any aggression from either of its territorial neighbours, especially China. Yet, declaring itself a neutral state, pursuing a policy of nonalignment, how not to use or not to be used by the 'third neighbours' against China or Russia demands Mongolia to exercise its 'smart power', as it were. The key to this art of neighbouring lies in how to avoid the political in the profound political solution to maintenance of Mongolia's sovereignty.

2 The Parliament of Mongolia on February 3, 2000 passed the 'Law of Mongolia on its nuclearweapon-free status', and on September $17^{\text {th }}, 2012$, the Permanent Representatives to the United Nations of the five Nuclear Weapon States (NWS) - the US, Russia, China, United Kingdom and France - and the Permanent Representative of Mongolia to the United Nations signed parallel political declarations regarding Mongolia's nuclear-weapon-free status (Nuclear Threat Initiative 2013). See also Defense Treaty Inspection Readiness Program (2010) for the comprehensive review of Mongolia's negotiation for a nuclear-weapon-free status. 


\section{Fortunate Neighbours, Unfortunate Neighbours}

Neighbour is a key metaphor in Christian moral philosophy, which has recently been taken on board to imagine a cosmopolitan world in which people are urged to treat immigrants, strangers, and other non-natives as neighbours whom we are obliged to love: 'love thy neighbour!' (Derrida 2004). The central attraction of neighbour lies in the idea of proximity which is expected to overcome enmity. However, paradoxically, neighbourly proximity is both an end and a means, for the concept of neighbour can be instrumentalized to serve a political purpose. The US 'Good Neighbour' policy was a prime example of the strategic use for assembling alliances, as it was designed to promote non-intervention and friendship with its southerly neighbours, and to secure Latin American support against the looming threat posed by Germany in the 1930s. ${ }^{3}$

The People's Republic of China has, since the 1950s, adopted a similar good neighbourly policy; inspired by the American model, but also rooted in traditional metaphor of neighbours being as close as lips and teeth (chunchi xiangyi 唇齿相依), it has been used to put moral injunction on China's neighbouring countries, emphasizing common interest (Lin 2005). In 2003, China broadened the scope of its good neighbour policy, pledging to promote an 'amicable, peaceful, and prosperous neighbourhood' at the same time proclaiming China's 'peaceful rise'. The two extra dimensions to the original idea of good neighbour ( mu lin 睦邻) - peaceful neighbour (an lin 安邻) and rich neighbour ( fu lin 富邻) (Yang 2004) - are no doubt designed to enhance China's own prestige by placating China's neighbours (Tsai et al. 2011).

The moral conception of proximate neighbourhood, I argue, is imbedded in sedentary metaphysics as exemplified in the wise saying: 'You can choose your friends, but you can't choose your neighbours'. The trouble is, as Slavoj Žižek (2005) shows, hatred and killing often occur between close neighbours. In Bosnia, the concept of neighbourhood called koms ${ }^{v} i l u k$ has become ambivalent, as it is torn between culturally expected intimate sociality and the murderous tensions among people in the same neighbourhood divided along ethnic lines (Bringa 1993, Henig 2012, Sorabji 2008). One may argue that proximity does not necessarily always lead to friendship; rather,

3 In order to assuage the fears of Latin Americans, on March $4^{\text {th }}, 1933$, Roosevelt announced in his inaugural address that: 'In the field of World policy, I would dedicate this nation to the policy of the good neighbour, the neighbour who resolutely respects himself and, because he does so, respects the rights of others, the neighbour who respects his obligations and respects the sanctity of his agreements in and with a world of neighbours' (Roosevelt 1933). 
precisely because of overlapping interests, maintaining a boundary between neighbours may be difficult but existentially essential. As Jacques-Alain Miller writes perceptively, 'For it is a simple matter to love one's neighbour when he is distant, but it is a different matter in proximity' (Miller 1994:79-80).

Conceptualized this way, geopolitics of neighbourhood can be the defining characteristic of a nation's foreign relations. Dana Cuff, in writing about the figure of the neighbour in suburban America, notes that the neighbour is both spatial and social. It is also 'political' in the sense of Carl Schmitt, which requires our wisdom to make a good distinction between a good and a bad neighbour (Cuff 2005, Schmitt 1996 [1932]). If we follow Mao Zedong, then, choosing to live with the right neighbour against the bad neighbour might be seen as the answer to one's survival and well-being. ${ }^{4}$ As shown by Mongolia's conceptualization of China and Russia as equal neighbours (so as to avoid conflicts) and those beyond as third neighbours (to 'soft-balance' the first two neighbours), the figure of neighbour has a built-in paradox of both the political and the anti-political. It may be both the problem and the solution to it.

Mongolia's third neighbour conceptualization, as I will analyze below, shows that peaceful coexistence of peoples and countries as neighbours lies as much in moral injunction as in having a freedom to choose neighbours, thereby reassembling a new neighbourhood. To the extent that Mongolia actively invites a cluster of nations and international institutions into Mongolia as third neighbours to flank the two territorial neighbours, we are witnessing a radical geopolitical reconfiguration of Inner Asia, transforming Mongolia from a hermit state landlocked between two mutually exclusive rival superpowers, to a nation sitting at the centre of a world community of neighbours in the making. This is in large part a product of Mongolia's own diplomatic initiatives.

The Mongolian approach may be best explained by Bruno Latour's sociology of translation, in which the aggregation of groups is the target of explanation, as opposed to what he calls sociology of the social which takes groups as a starting point (Latour 2005). As such, what we need to do is to explain how Mongolia has tried to reassemble a new omni-neighbourhood in Mongolia, whether a new cosmo-polity is emerging in Mongolia, and what characteristics it may have.

Latour's sociology of translation suggests that an association or group is not always comprised only of humans. Non-humans can also play an

4 'Who are our enemies? Who are our friends? This is a question of the first importance for the revolution. The basic reason why all previous revolutionary struggles in China achieved so little was their failure to unite with real friends in order to attack real enemies' (Mao 1925: 249). 
equal role, exercising agency. I think it is an important insight useful for understanding the formation of new neighbourhood in Mongolia, but we must at the same time reject Latour's flat ontology. For not all things have the same weight in their exercise of agency, nor do people have equal power or status. Context, history, and culture determine the shape, duration, and meaningfulness that each association or neighbourhood takes.

Giovanni da $\mathrm{Col}$ (2012), in a recent article in which he develops a concept of cosmoeconomics, argues that Tibetan cultural and social life is centred on fortune, or yang, and managing one's fortune is 'the elementary form of fortunate life (da Col 2012: 192). Fortune is the vital force of either an individual or a group, but it is perforce to be shared: 'Good fortune has to be shared and redistributed properly and is the medium that connects, shapes, and re-creates social networks through the economies it entails. But it requires constant care to avoid free-riders and parasites' (da Col 2012: 192). Put differently, too much fortune may, like a piece of rotten meat, attract a lot of flies, making you unfortunate. I build on this argument and suggest that fortune and its sharing or unsharing may lead to regrouping and formations of new political associations.

While da Col's fortune is something invisible, unquantifiable, and yet has a 'quasi-relational materiality' as it can be preserved, contained, or appropriated, and it can flee or disappear of its own volition due to external influence, and such as it is a generalized fortune, I would like to focus on something specific to locality that may contain the fortune that makes the people of the locality particularly fortunate and prosperous, and yet precisely because of this quality it is subject to desire from outsiders. I call it the fortune-sovereignty of the people inhabiting the territory. My conception of fortune-sovereignty goes beyond the Eurocentric and modernist understanding of sovereignty as something exclusive with a bounded essence; fortune-sovereignty not only posits relationality, often hierarchical and overlapping, but involves exchanges of fortunes between various sovereign realms that result in regional dynamics. ${ }^{5}$ The best term that captures this sense of fortune-sovereignty is the Chinese concept of fangwu (方物) which refers to things specific to a region. Fangwu, in Chinese conception, is both cosmoeconomic and cosmopolitical.

5 Aihwa Ong has recently put forward a similar concept of 'graduated sovereignty' to understand the distributed, non-exclusive characteristics of East Asian state sovereign power between the centre and special economic zones, where the citizenship is defined differently according to race, ethnicity, gender, class and region, and where foreign corporations are allowed in to exercise certain authority (Ong 2006). 
Take for example the classical Chinese schema of tianxia (天下). It is a five or nine concentric circle of peoples whose degree of humanity or civilization is measured by a gradation of distance from the centre. ${ }^{6}$ It is in practice a combination of political authority and economic fortune; that is, the prestige and authority of the centre must be sustained by tribute bearing from the periphery. The tributary items - fangwu - from the periphery are not just symbolic, but represent the fortune-sovereignty of the realm; in return the peripheral leaders get more value-added goods as gifts, i.e. the fortune-sovereignty from the emperor's realm, but political subordination to the supreme authority of the centre. James Hevia comes close to capturing the essence of the cosmopolitics of this fortune-sovereignty:

[T]ribute is glossed in Chinese-language sources as local products (fangwu), that is, things specific to the kingdom of the ruler who presented them to the emperor. The emperor, in turn, bestowed things from his kingdom on the other ruler. This exchange of precious objects was understood to forge a political relationship between the Qing emperor, as the superior, and the other ruler, as inferior, the purpose of which was nothing less than the mutual undertaking of the cosmic-moral ordering of the world. The objects themselves and their specific movements, I would argue, cannot be reduced purely to economic or cultural values. Rather, they are performative gestures in that they had a role in producing political and even natural relations. (Hevia 2003: 15-16) ${ }^{7}$

6 The Chinese classic Rites of Zhou ranked nine domains of imperial administration starting from the residence of the ruler, with required service specified in the tributary relations: (The ruler) distinguished between the nine domains or areas of service ( $f u$ 服) among the vassal states. The area covering one thousand $l i$ (from the emperor) is called the Royal Capital Domain (Wangji 王畿). The area five hundred $l i$ beyond the Royal Capital Domain is the area called the Marquis Area of Service (Houfu 侯服). The area five hundred li beyond the Marquis Area of Service is the area called the Master of the Hinterland Area of Service (Dianfu 甸服). The area five hundred $l i$ beyond the Master of the Hinterland Area of Service is the area called the Baron Area of Service (Nanfu 男服). The area five hundred li beyond the Baron Area of Service is the area called the Pledged Official Area of Service (Caifu 采服). The area five hundred $l i$ beyond the Pledged Official Area of Service is the area called the Guard Area of Service (Weifu 卫服). The area five hundred $l i$ beyond the Guard Area of Service is the area called the Man Barbarian Official Area of Service (Manfu 蛮服). The area five hundred li beyond the Man Barbarian Official Area of Service is the area called the Yi Barbarian Official Area of Service (Yifu 夷服). The area five hundred li beyond the Yi Barbarian Official Area of Service is the area called Defense Commander Area of Service (Zhenfu 镇服). Lastly, the area five hundred li beyond the Defense Commander Area of Service is the Barbarian Border Official Area of Service (Fanfu 藩服) (Quoted in Anderson 2007: 22).

7 See also Hevia (1995: 128-130). 
This schema is predicated on the abundance of China's fortune-sovereignty, a vital force that China often had to share with non-Chinese peoples, albeit in attempted exchange for the latter's political loyalty and subordination. This sharing of the fortune-sovereignty was often a dangerous undertaking, for often the peripheral peoples would attempt to conquer and occupy China in part or in whole, turning China's 'cherished men from afar' into 'perilous neighbours' (Barfield 1989). The history of China oscillates between these two sets of dynamics: on the one hand, the Chinese imperial imperative determines centripetalism, as its centrality must be sustained by tributebearing from the periphery, which must be beckoned and cherished. On the other hand, it builds up walls to protect itself from so-called 'greedy' nomadic neighbours (di Cosmo 1994) whose tribute-making became a way to exploit China, as they tried to wrestle more in the missions. There were times when peripheral leaders were told not to come to pay tribute, and China engaged in active defence by building walls, or expelling 'barbarians'. What it implies is that, I argue, China's fortune-sovereignty - its specific material abundance - had the potential to become the source of its misfortune, the aversion of which requiring astute management. The management of fortune-sovereignty is the elementary form of the Chinese cosmopolitics.

The geoeconomic and cosmopolitical perspectives as outlined above can perhaps explain Mongolia's transformation from a conquest people to one looking inward to defend themselves. I argue that it was this transformation that brought China to become Mongolia's 'perilous neighbour', and making Mongolia lose its own capacity to be China's worthy neighbour. In other words, I suggest that a neighbour is not an individual or group that is territorially close to someone fortuitously. To be a neighbour is to be oriented to someone's fortune-sovereignty, thereby becoming a force to be reckoned with.

What, then, is the fortune-sovereignty of Mongolia? I have elsewhere argued that during the Qing era, the Mongols were largely kept separate from the Chinese with the Great Wall and the Willow Palisade serving as their borders. The Mongols' nationalist involution was therefore the product of the Qing management of the Mongols, who were given a sense of territorial boundary, which they were to defend (Bulag 2012b). Moreover, the Mongols were given to develop a sense that their land was rich, as there emerged a plethora of place names with the word 'bayan', wealthy or rich: bayangol, bayanhot, bayanbogd, bayantsagaan, bayanhongor. Like the Tibetans, Mongols began to think in terms of fortune, heshig, which is located in pastures, mountains or rivers or lakes (for studies of Mongol practice of beckoning or increasing one's fortune, see Chabros [1992], 
Empson [2011], Humphrey and Ujeed [2012]). Mongols began to think that they were the most 'fortunate' and 'blessed' people in the world in terms of their material well-being. This was no doubt the product of the Qing policy of territorialization of the Mongol banners, their princes being obliged to regularly worship mountains and rivers which were believed to be fortuneproviders (Ts. Nasanbaljir 1964).

Such cosmoeconomic transformation had direct bearing on the Mongolian cosmopolitical configuration. In the late nineteenth century, there emerged legends about golden horses or golden cattle, which, once grazing on luscious pastures or swimming under lakes, are either stolen by southern barbarians (nanmanzi南蛮子) or Chinese, and occasionally Russians, or running away, startled by the strangers. These legends tell of the massive arrival of the Chinese and Russian settlers in Mongolia, and Mongol heroic defence of their pasture and salt lakes (Bulag 2010:167-197, Chen 2001). Such legends of loss of fortune-wealth show an irony of Mongolia's misfortune stemming precisely from their rich endowment of natural resources, and the Chinese and others turning from a victim fleeing Mongols to ones settling in Mongolia and among the Mongols as aggressive neighbours.

Whether or how to share Mongolia's fortune-sovereignty with nonMongols thus became an existential question for Mongols at the turn of the $20^{\text {th }}$ century. I argue that the $20^{\text {th }}$ century Mongolian independence must be understood in this new cosmopolitical and cosmoeconomic context, which constituted a structure of opportunity, an opportunity for Mongolia to exercise its agency to form its own polity. By structure of opportunity I mean that these expansive powers were all mutually exclusive, all wanting to encompass Mongolia into their own polity, either formally or informally. I have recently developed a concept called 'collaborative nationalism' to capture the characteristics and dynamics of Mongolian nationalism (Bulag 2010). Mongol nationalism, that is a desire to build a nation-state on historical Mongolia, was waged through bringing in and forming a united front with a third party against a major adversary. In triangulating the relationship, the Mongols developed agential capacity to judge and decide how to use their fortune both to cut networks and build new ones.

My point of collaborative nationalism is that nationalism is not always a practice of bowling alone, to use Robert D. Putnam's (2008) apt phrase, but is often collaborative with putative friends against putative enemies, and the biggest challenge to collaborative nationalism is how to manage the shared fortune-sovereignty with the friends in the absence of the enemies after they are defeated. Indeed, in the twentieth century, Mongols suffered more in the hands of their Soviet Russian friends than their enemies, 
Chinese or Japanese. Most of Mongolia's leaders were killed by the Soviet Russians. The Soviet Union stationed a massive army in the 1930 s and 40s, and from 1966 to 1991, and operated secret uranium mines and railways. This friendship was both necessary and hugely costly, and it was even colonial, not because of the inherent evilness of the Russians, but because of the strategic necessity of collaborative nationalism. Mongols have to share their fortune-sovereignty with a friend in order to avoid the possibility of its complete loss in the hands of an adversary, who was perceived to represent 'threat', rather than simply 'power', according to the 'balance of threat' theory proposed by Stephen Walt (1985).

Since the 1920s, Mongolian politicians have been attracted to the Switzerland model to maintain neutrality, but this has never been a real option. From the early sixties, landlocked, exploited by the Soviet Union, and yet deeply suspicious of China, Mongolia embarked on a road to internationalize itself by joining the UN and establishing diplomatic relations with as many countries as possible (Altangerel et al. 2013, Campi and Baasan 2009): another round of collaborative nationalism.

As is clear, Mongolian collaborative nationalism is not just relational, but also organizational, as it aims to form partnerships, and it is as strategic as it is flexible, depending on the Mongol judgment of the fluctuating qualities of its territorial and non-territorial neighbours, such as their aggregate strength, geographical proximity, offensive capabilities, and offensive intentions. One may argue that flexibility is not necessarily a monopolistic property of late capitalist accumulation as David Harvey (1989:141-172), or Chinese negotiation with global capitalism in the face of political uncertainty as Aihwa Ong (1999) would have it. Flexibility is in fact a distinct feature of Mongolian territoriality, and it is the traditional mechanism to maintain peace or wage warfare.

Consider the rural Mongolian residential pattern. The smallest residential community in Mongolia is called hot ail. This is a partnership community with several families congregating to share labour and pasture, forming a neighbourhood, called after the shared fortune or property: neg usniihan, people of one water source; neg goliinhan, people of one river, and so on. The members could be relatives or friends, and the size of the community could be constant, as some families move in or out, depending on how they get along. The flexibility or possibility of moving away from the neighbourhood means Mongols have freedom to decide whom to choose to live next to. To be sure, there are as many impossibilities as there are flexibilities, but my general point is that Mongols do have a tradition of not only choosing a neighbour or neighbours, but also forming a neighbourhood or an 
aggregation based on common interest. I call this flexible neighbourhood. Mongols do not bowl alone, but form alignment to confront an adversary or venture for a fortune.

My concept of flexible neighbourhood has the advantage of capturing not only the flexible form and size of neighbourhood, but also the agencies of actors. To be a member of a neighbourhood, or to rally familial units to form a community, one has to have sufficient capital, social or economic, and they constitute complementarities thereby achieving an organic unity, to use Durkheim's phrase. This flexibility characterizes social dynamics in Mongolian history, especially from the twelfth century to the eighteenth century. The Manchu tried to destroy this flexibility mechanism by dividing up Mongols along banner lines, but within a banner, flexibility continued. The new spirit of flexibility is precisely how to work against the fixed territorial grain to form a flexible neighbourhood of nation-states in the world.

Following the cosmoeconomic-cum-cosmopolitical perspectives and that of flexible neighbourhood, I suggest that today, as Mongolia discovers world class mines of coal, copper, and gold - the fortune or the source of energy vital for Mongolia's economic rise - a new round of neighbouring is now taking place. The proximity of these mines, many of which have been declared 'strategic deposits' by the Mongolian government in 2007, to the Chinese border, and the fact that China is the largest market for these minerals, as China needs these resources to energize its own economy, all point to the fact that Mongolia's fortune-sovereignty will have to be shared with China as a 'greedy' neighbour. How to share this fortune-sovereignty has become a question of how to keep Mongolia fortunate; it is also indicative of Mongolia's art of neighbouring.

\section{Reassembling Neighbours in Mine-golia}

In spring 1990, Mongolia became the first Asian communist country that embraced democracy. Quickly Mongolia's career diplomats, now wearing a hat of democracy, went out on a new mission; democracy, as an ideological resource, did its magic as an 'actant' not only to allow Mongolia to join the international community of democracies but also bring them in to form Mongolia's new flexible neighbourhood. Mongolia's strategy paid off, as the US led a group of donor countries to provide Overseas Development Assistance to Mongolia.

With China being defined as a neighbour, after normalizing relations in 1989, Mongolia opened its door for Chinese investment to compensate for 
the withdrawal of Russian investment. Much of the Chinese capital went into small coal mines in Mongolia as Mongolia issued thousands of licenses, almost for free, in a bid to attract foreign investment. However, for much of the 199os, despite the in-flowof foreign aid, Mongolia languished in poverty, due no small part to, inter alia, the international reputation Mongolia enjoyed as a country of pastoral economy, collapse of infrastructure, and shortage of skilled labour.

This situation began to improve at the turn of the new millennium, when the Canadian company Ivanhoe Mines discovered world class gold-copper ore deposits in a place called Oyu Tolgoi, or Turquoise Hill in the Gobi Desert, only 80 kilometres from the Chinese border. As more world-class mineral deposits were discovered, and international investment poured in, the Mongolian government decided to exploit the mine together with Ivanhoe and the Anglo-Australian mining giant Rio Tinto exclusively. In 2009 they agreed on a 34 percent Mongolian government and 66 percent Ivanhoe and Rio Tinto investment deal.

Ivanhoe and Rio Tinto's entry into Mongolia quickly transformed Mongolia into Mine-golia (Bulag 2009), as minerals have been recognized as the nation's new fortune-property to make it prosperous. However, the Mongolian government's willingness to allow 66 percent share control by Ivanhoe and Rio Tinto happened at a time of heightened nationalist anxiety over China's massive investment in Mongolia. There was a rising anti-China sentiment against its perceived threat to Mongolia's national security (Rossabi 2005). I argue that Mongolia's deal on Oyu Tolgoi followed the logic of 'collaborative nationalism', that is to bring in powerful international companies from Mongolia's 'third neighbours' to 'balance' China's preponderance of investment in small mines, and Russian control of Mongolia's large copper mine of Erdenet. In doing so, Mongolia enacted a political expectation of Ivanhoe and Rio Tinto to be different from Chinese companies or Russian companies. In other words, the Mongols expected corporations from the 'third neighbours' to demonstrate altruism to Mongolia.

In 2010, Mongolia renewed its 1994 National Security Concept. According to Reeves, the renewal was a culmination of gradual shift from an omnienmeshment strategy to one of combining omni-enmeshment with balance of influence, identifying China as Mongolia's biggest national security concern (Reeves 2012). I would add that the new National Security Concept has elevated the 'Third Neighbours' to the same level as the two territorial neighbours, while avoiding a political naivety enshrined in the previous conception. Mongolia's resource nationalistic stance towards Rio Tinto as shown in the recent calls for renegotiating the deal represents a belated 
realization that the 'Third Neighbours' may have their own self-interest in investment into Mongolia's vital mineral sectors.

One clause in the new National Security Concept is particularly striking: 'External factors which may adversely affect the ensuring of economic security: Direct dependence on any one country in economic branches of strategic importance' (Embassy of Mongolia n.d., Chapter 5, article 33). This clause is usually interpreted as a 'one third' rule, i.e. a proportional and equal representation of the three neighbours' economic interest in Mongolia. The rule is thus an indication as much to curb China's domination in Mongolia as a realization of the limited power and indeed the self-interest of the third neighbours who may strike better deals with China or Russia to the detriment of Mongolia's national interest, or fall afoul of Mongolia's two territorial neighbours. In 2010 Mongolia put Tavan Tolgoi, the world's second largest coking coal deposit, to international bidding, not limited to the 'third neighbours' alone. Indeed, 'third neighbours' were to be just that, 'one third' in Mongolia's three-member neighbourhood. In Mongolia's new strategic thinking, the three neighbours must be brought in to achieve some kind of equilibrium on which Mongolia's national sovereignty will rest.

In 2009, shortly before the bidding, three of Russia's highest leaders visited Mongolia in succession: the Prime Minister Putin in May, President Medvedev in August, and Speaker of the Upper House, Sergei Mironov, in September. In June 2010, the Chinese premier Wen Jiabao visited Mongolia. 2011 saw an unprecedented number of foreign dignitaries: the President of India, Pratiba Davinsingh Patil in July, South Korean president Lee Myungbak and US vice president Joe Biden in August, Finnish President Halonen August $31^{\text {st }}$ - September $1^{\text {st }}$, German Chancellor Merkel in mid-October, Austrian president Fischer in December, all coming with impressive packages of offers, all expressing interest in getting a share of Mongolia's strategic fortune-sovereignty - coking coal.

As Mongolian politicians calculated correctly, suddenly Mongolia became a major destination for world leaders, as many of them have taken up on the Mongolian coal rush. The Mongolian government's strategy of assembling a world community of neighbours through its one-third rule can be gauged in its choice of the international bidders for the Tavan Tolgoi Mine in 2011: China's Shenhua was given 40 percent, America's Peabody 24 percent and a Russia-Mongolia consortium 36 percent. More interestingly, apart from America's Peabody, the other two entities were not singles, but each being a consortium itself: The Russian-led consortium included South Korea's POSCO, utility firm KEPCO, trading firm LG Corp and Daewoo International, state-owned Russian Railways and Japanese trading houses 
Itochu Corp, Sumitomo Corp, Marubeni Corp and Sojitz Corp. China's consortium comprised China's Shenhua and Japan's Mitsui \& Co. This was an omni-enmeshment plus interlocking of interests indeed. Surprisingly, the Mongolian National Security Council vetoed the deal immediately after other South Korean and Japanese bidders cried foul. The rejection was not so much a negation of the intention of balancing as a collision between rigidity of the new security concept and the pragmatics on the ground. The search for bidders continues at this time of writing.

The Mongolian state's strategy can also be seen in the construction of new railway lines to ship the mineral products to the world markets. As a land-locked nation, Mongolia does not have its own sea port; its nearest port is China's Tianjin. Since both Oyu Tolgoi copper mine and Tavan Tolgoi coal mine are located near the Chinese border, which could be accessed by building a two hundred kilometre long narrow-gauge $(1,435 \mathrm{~mm})$ railway from the mines to link to the existing Chinese railway network, it has been an option strongly favoured by all the mainstream international experts and financial institutions, including the World Bank and the Asia Development Bank. After prolonged debates, in December 2010, the Mongolian parliament resolved to construct a 1,100 kilometre-long internal wide-gauge $(1,520 \mathrm{~mm})$ railway line in the first phase, and it was to link to the Trans-Mongolian railway and further east to connect to the Russian railway system and the Russian Far Eastern ports of Vanino or Vostochnii, in order to ship Mongolia's minerals to its two close third neighbours, South Korea and Japan. As Munkh-Ochir, a Mongolian defence strategist writes, 'This decision seems to reflect a cohort of other-than-economic considerations - geopolitical calculations, aspirations for sustainable industrialization, and finally public opinion, which matters as the new electoral cycle unfolds' (Dorjjugder 2010).

Mongolia's national strategy on railway construction was political; as such it seemingly trumped all the economic rationality. It was a reaction to the Chinese government's shutdown of the railway at the Sino-Mongolian port of Erlian in 2002 for several days during the visit of the Dalai Lama to Mongolia, ostensibly for 'technical reasons'. In this light, precisely because of the unpredictability of the Chinese government which often uses its economic muscle for international relations, Mongolia's political decision also has had its economic calculation not to become hostage to China, but always allow for an alternative exit. Yet in line with Mongolia's overall strategy, the railway decision must not be construed as shunning China, for China is and will be Mongolia's largest market. Indeed, Chinese capital is eagerly sought for building the new planned railways. On October $24^{\text {th }}, 2014$, after four years of gruelling, and oftentimes debilitating, debates with high 
pressure from both China and Russia, the Parliament of Mongolia approved the construction of four railway lines: two railway lines to be linked to the Chinese railway system will use the narrow gauge, and the other two - a line from the Mongolian copper city Erdenet to the Mongolia-Russian border into Tuva, and the planned horizontal line of the Mongolian national railway network from the mineral-rich South Gobi to the east, will use the wide gauge (Parliament of Mongolia 2014).

As can be seen, China is actively invited in, but the proportion of the Chinese share of Mongolia's fortune-sovereignty will be equalized with its other territorial neighbour, Russia. This is exemplary of Mongolia's new strategy of building a world community of neighbours par excellence.

It remains to be seen whether Mongolia's neighbourhood strategy will work eventually, but what is clear is that Mongolia's art of neighbouring with China is through assembling as many neighbours as possible, inviting them into Mongolia. This situation is somewhat reminiscent of the Chinese tianxia and the tributary system. Like an ancient and wealthy agrarian Chinese empire, a mineral-rich Mongolia is now receiving tribute-like missions from powerful countries, all wanting to make profit out of it. Unlike the Chinese emperor who wanted to capitalize on the tributary missions to enhance his own prestige as the supreme lord of universe, Mongolian leaders' ambition is perhaps more mundane, that is, they want to transform these potential threats into forces that can ultimately guarantee Mongolia's sovereign survival and economic prosperity. This is to be achieved not only through a delicate balancing act, keeping all of them at equal distance or closeness, but also through sharing its fortune-sovereignty with all of them, and finding a mechanism to interlock all of their interests together, rather than pitting them against one another.

\section{Cosmoeconomics of 'Horspitality', or How To Be Happy Neighbours?}

On November $21^{\text {st }}, 2005$, the US president Bush came to Ulaanbaatar to thank Mongolia for its staunch support for the U.S. war effort in Iraq, and particularly to thank the Mongol soldiers for intercepting suicide bombers at the gate of a US military camp, saving hundreds of US soldiers. "This visit has historical significance because it proves that Mongolia has a third neighbour', Mongolian president Enkhbayar said as he introduced Bush (The Washington Times 2005). 'America is proud to call you the third neighbour', Bush responded (2005). A better and more appropriate response would 
have been 'America is proud to be your third neighbour', but never mind Bushisms. This was the first time that the US officially and openly accepted Mongolia's formula and acknowledged a neighbourly relationship between them, 15 years after James Baker first proposed so to Mongolia. Neighbours in need, neighbours indeed.

In his address to the Mongolian parliament, Bush said he had a second mission, 'I'm here on an important international mission. Secretary Rumsfeld asked me to check on his horse' (Bush 2005). He referred to a diplomatic gift horse ${ }^{8}$ given to Rumsfeld by the Mongolian Ministry of Defence during his visit just a month prior to Bush's visit. Instead of taking the horse back to the States, Rumsfeld left it in Mongolia, and it was left in the wild to roam freely. The American press at the time was amused, if not embarrassed, not so much at the seemingly worthless Mongol gift, as at the possible indication of the US desperation to rely on a small and poor nation with a belligerent history of war.

A Mongolian horse, a common species, is certainly far less impressive than some rare species, such as panda, as a diplomatic gift to show one country's good will (for an in-depth discussion of animal-human neighbourly relations in the Chinese context, see Fiskesjö, this volume). I suspect Mongolian diplomats did a poor job in explaining the real significance of a gift horse apart from emphasizing that the given horse is a pure breed or a champion horse in a national naadam competition. Still less did they possibly explain why the horse ought to be kept in Mongolia instead of taking away.

Rumsfeld was not the first to get a Mongolian horse. When the Japanese Prime Minister Toshiki Kaifu, the first national leader of a democratic country arrived for a visit in early August 1991, the Mongols gave him a horse. ${ }^{9}$ Less than two weeks later, when the Chinese president Yang Shangkun came for a visit, Mongols also gave him a horse. Neither of them took away the horses. A more recent American politician to get a horse was the US vice president Biden in 2011. ${ }^{10}$ A US journalist called Evan Osnos wrote a piece entitled 'Equine Diplomacy' on The New Yorker, complaining that the Mongols had even given gift-horses to Soviet leader Leonid Brezhnev and the Romanian dictator Nicolae Ceausescu. Moreover, he claimed that he failed in his self-appointed mission to find Rumself's horse, writing: 'As for

8 Rumsfeld named it Montana, after his wife's home state which resembles Mongolian steppe.

9 He named the horse Kaishun. Kai is from his family name and Shun is from Japanese word Shunme that means fleet horse.

10 Biden named the horse 'Celtic', after his Irish origins. 
Rumsfeld's horse, I never found him. By the end of my trip, the [Mongolian] defence ministry told me that the horse was back in Khentii province, birthplace of Genghis Khan. I was welcome to keep looking for him in the province, an area the size of Austria' (Osnos 2011)."

The former Japanese Prime Minister Kaifu was far more gracious in his appreciation of the horse he received. In August 2006, at a ceremony marking the $800^{\text {th }}$ anniversary of the founding of Chinggis's Great Mongolia in 1206, which I also attended, I heard Kaifu reminiscing how he still checked on his Mongolian horse through the Japanese embassy. In October 2011, the newly appointed Japanese Ambassador Takenori Shimizu to Mongolia paid a courtesy call on Kaifu, and Kaifu started his conversation with his Mongolian horse:

At the time of that visit, I was deeply impressed by a gift horse I received from the then President Punsalmaagiin Ochirbat. That was a prized horse that had won in Naadam (the national sports festival of Mongolia). I heard that in Mongolia, a horse is a really considerable gift. However, although I was very grateful, I had no place to keep the horse if I brought it back to Japan, so I thought it would be very unfortunate for the horse. Therefore, when I returned I just brought back its reins. (Japan News 2011)

He also recalled how he was deeply impressed by the Mongolian 'emotional intelligence':

My visit to Mongolia was the first as Prime Minister of Japan and it was also the first by a leader from the West after democratization, so it was an extremely good thing. When I visited the country again some years later, I was eating a meal at a restaurant when I could hear a horse's cry. As I was wondering what was happening, I saw that Kaishun, my horse, had been brought to me by the people taking care of him. I was once again deeply moved by the consideration for me. I thought that this could truly be called heart-to-heart communication. The people of Mongolia have strong compassion, or perhaps I should say an emotional heart. I think their mentality is similar to that of Japanese people. (Japan News 2011).

11 The latest to get a Mongolian gift horse was the US secretary of Defence Chuck Hagel in April 2014. Helen Cooper, a New York Times journalist covering Hagel's visit, wrote that the American fatigue at receiving equine gifts from Mongolia was largely for logistical reasons. They left their horses back in Mongolia because they wouldn't want American taxpayers to bear the cost of their upkeep (Cooper 2014). 
I am not sure that Kaifu really understood Mongolian mentality; what he exhibited was perhaps more of his own mentality. The significance of the gift horse must be examined both historically and in the way Mongols conceptualize the human-animal relationship. Historically, horses were Mongol 'local products' presented to the Qing emperor as an obligatory tribute. In 1655, the Qing granted zasag (ruling prince) titles to eight princes of the Khalkha, and demanded that the Khalkha make an annual tribute of one white camel and eight white horses to the Qing emperor. The offering of nine whites was institutionalized in 1691 when the Khalkha finally submitted to the Qing (Bawden 1989 [1968]: 102). Thus, viewed historically, presenting a horse gift is not an innocent, but profoundly cosmopolitical act. In other words, during the Qing dynasty, the Mongol submission was annually expressed by surrendering the fortune-sovereignty in exchange for gifts - the fortune-sovereignty of the emperor - and trade rights.

The practice of presenting a gift horse to a guest and leaving it behind in the wild has a more cosmoeconomic dimension. It is usually the case that the Mongols create a specific relation between a person or family and an animal. In creating this association, this individual animal undergoes a consecration ritual called seter, which means henceforth, this particular animal is sanctified, never to be drafted for labour or killed for food (for a brief description of seter, see (Hyer and Jagchid 1983: 88-89). In consecrating the animal, it is believed that the fortune of both the owner and his animals of the same species will increase. As Tani writes, hunters and herders 'justify their killing and consumption of animals by prohibiting the slaughter of a special individual held to be responsible for the herds' prosperity' (Tani 1996: 45). Fortune or heshig may be present everywhere and among all, but it is through identification through naming and setting free an animal that one secures his or her own individualized fortune. Thus, I would argue that presenting the gift-horse is precisely an act to share Mongolia's fortunesovereignty with the honoured guest, so that his fortune may also multiply. Presenting a horse and performing the seter is indexical to the Mongol sense of fortune and happiness. With the fortune of Rumsfeld and Biden, and that of Kaifu ever accumulating in Mongolia, it is hoped that Mongolia and its third neighbours will not only share Mongolia's fortune-sovereignty, but also share happiness together.

As we have seen, the Japanese Prime Minister had an emotional reunion with his gift horse fifteen years later. Since his retirement from politics in 2009, Kaifu has been serving as President of the Japan Mongolia Cross Link Association. In October 2011, Rumsfeld also came back to Mongolia, to 'thank the country for their outsized contributions to theUS-led Global 
War on Terror and to promote stronger ties between the US and Mongolia' (American Chamber of Commerce in Mongolia 2011). During the occasion, the Mongols brought back his Montana from the steppe for a reunion with his master (Rumsfeld Office 2011). It is said that the Soviet leader Leonid Brezhnev took away his Mongolian gift horse immediately, so it was probably never consecrated with a seter. As for the Chinese president Yang Shangkun's horse, it was kept in Mongolia until 2002 when it was sent to China, four years after Yang's death. A neighbour that shares fortune-sovereignty, but refuses or does not know how to share happiness, is inherently unfortunate.

\section{Smart Power and Pax-Mongolica in the $21^{\text {st }}$ Century}

I have so far discussed the geopolitical reconfiguration of neighbourhood between Mongolia and China through changing fortune; the reverse of fortune has turned China from a passive neighbour to an active neighbour, from a neighbour that repeatedly tried to wall itself against invaders or expel the conquerors to one that began to actively expand into Mongolia. The closing in of external powers in addition to China as a result of the reverse of Mongolia's fortune, created a situation not entirely unfavourable to Mongolia, however. To the extent that Mongolia's neighbourhood building aims to create a new security structure so that Mongolia's economic prosperity and national sovereignty are guaranteed, we need to examine what measures Mongolia has taken towards that end. Indeed, Mongolia's geopolitical environment is unadmirable. With a border of 4,710 kilometres with China, but less than 20,00o troops in total, China could occupy Mongolia within a day if it wanted to. Mongolia has every good reason to fear a rising China, not least because, for the greater part of their interactive history, China had suffered in the hands of the Mongols repeated loss of territory, people and even death of state (wang guo 亡国). It is now the turn of the Mongols to fear the worst, for there is still a powerful undercurrent in China to regard Mongolia as a breakaway territory by virtue of China's claim to be a successor state to the Qing Empire, of which Mongolia was once an important part (Bulag 2012a). In this regard, then, 'China threat' is not something entirely new, and an assertive China is, to Mongolia, not a sudden change from a sleeping beauty to an awakened roaring lion. How to deal with such a neighbour is, as we have seen, the core of Mongolia's national security consideration and constitutes the essence of Mongolia's international diplomacy. 
However, if Mongolia's persistent and eventually successful pursuit of 'single-State nuclear free zone' is any indication, Mongolia's approach to its national security is precisely through peace promotion. In the 1990s, Mongolia pre-empted the China threat by renouncing territorial pan-Mongolism, deciding not to support Inner Mongols in their struggle for independence. Mongolia was also lucky during the period, because China adopted Deng Xiaoping's dictum of self-restraint (taoguang yanghui 蹈光养晦) in its foreign policy, aiming to create a safe international environment for its economic development. While both sides intensified their commitment to good neighbourly posture, at the turn of the new millennium, Mongolia's geopolitical environment had fundamentally changed.

One of the important developments at the beginning of the $21^{\text {st }}$ century was the formation of the China-led Shanghai Cooperation Organization in 2001, comprising China, Russia, and four of the five Central Asian republics: Kazakhstan, Kyrgyzstan, Tajikistan, and Uzbekistan. Both China and Russia actively encouraged Mongolia to be a member. Mongolia is attracted to the SCO principle that emphasizes 'mutual respect of sovereignty, independence, territorial integrity of States and inviolability of State borders, nonaggression, non-interference in internal affairs, non-use of force or threat of its use in international relations, seeking no unilateral military superiority in adjacent areas (Shanghai Cooperation Organisation 2006) But it is also acutely aware that the SCO is intended as a rival to the US-dominated NATO, and it excludes most of Mongolia's third neighbours. Thus, Mongolia only applied for an observer status, refusing to join it as a member.

The 9/11 terrorist attacks on the US and the subsequent US war in Iraq and Afghanistan offered an opportunity for Mongolia to get out of this straightjacket. Responding to the US call, Mongolia joined the US-led 'coalition of the willing' to disarm Saddam Hussein, and contributed to the UN peace-keeping operations. More recently, on November $21^{\text {st }}, 2012$, Mongolia became the $57^{\text {th }}$ participating state of the Organization for Security and Co-operation (2012) in Europe, in which it has been active since 2004 . Mongolia's active participation in the international collective military operation is an effort to secure and develop its position in the world by extricating itself from the Chinese and Russian spheres of influence, and as such it is exemplary of small states who 'are more likely to use international organizations as their preferred foreign policy tool (Hey 2003:4)

While this may be the intention of any small state faced with a security threat, what needs to be explained in our case is the ability of Mongolia as a small and weak state to attract its third neighbours to value its contribution and consider it as a worthy neighbour. In the absence of any 
military strength, paradoxically, Mongolia's military contribution cannot be assessed in terms of hard power, but only in terms of soft power, which, in Joseph Nye's original formulation is, 'the ability to get what you want through attraction rather than coercion or payments. Further, it arises from the attractiveness of a country's culture, political ideals, and policies to get what you want through attraction rather than coercion or payments (Nye 2004: 10). This is not a moment to make a list of Mongolia's soft power; what I am interested in is whether Mongolia has 'smart power' to build a neighbourhood of peace.

Since 2001, an annual military exercise called Khan Quest has been organized in Mongolia by the Mongolian Armed Forces General Staff in conjunction with the US Pacific Command (PACOM). China and Russia responded to the American entry into Mongolia by launching their first joint military exercise since their alliance in Far East Russia's Vladivostok and in China's Shandong Peninsula from August 8 to 25, 2005. The US Secretary of Defence Rumsfeld and President Bush's visits to Mongolia in October and November in the same year were not just to express the US appreciation for Mongolia's steadfast support to the US war effort, but also to warn China and Russia to stay away from Mongolia. However, although Bush told a Mongolian reporter that the US would help Mongolia under military threat, saying 'We will support our allies for sure if a war cannot be avoided', a week after his visit, the Mongolian president paid an official visit to China. A China-Mongolia joint statement in Beijing declared that neither party would participate in any military-political alliance directed against each other and would not conclude any treaty and agreement with a third country that may adversely affect the interests of each other (United Daily News 2005:13).

Whatever the US intention, Mongolia has faithfully stuck to its Concept of Foreign Policy and its Concept of National Security adopted in 1994 that Mongolia would not provide a military base to any foreign country, and it would pursue a policy of non-alignment. The 1994 National Security Concept stated that Mongolia's 'military-political security can be ensured through a collective security system by joint efforts or participation in such a system'. What Mongolia had in mind was to transform its defence force into the international peace support and UN peacekeeping operations - a total internationalization of Mongolia's national defence.

In 2002 the Mongolian Parliament passed legislation that regulates participation of Mongolian military and civilian police personnel in UN peace operations. In 2006, against the tough joint Chinese and Russian military response, Mongolia deftly established a Peacekeeping Training Centre as 
part of their Five Hills Training Facility, and launched an expanded military exercise involving 22 Asia-Pacific countries. Mongolia thereby became the first country in the region to organize a multinational peace support operations Command Post Exercise as well as Field Training Exercise with the Global Peace Operations Initiative of the US government. In 2007, the participants included Australia, Bangladesh, Brunei, Cambodia, France, Germany, India, Indonesia, Nepal, Singapore, South Korea, Sri Lanka, the Philippines and Tonga, as well as Mongolia and the US.

In addition, since 2004, Mongolia has held annual bilateral military exercises with India, the so-called 'spiritual third neighbour' of Mongolia, and has called the exercise Nomadic Elephant since 2007. Since 2008 Mongolia and Russia have held annual anti-terror military exercises in Mongolia, and China and Mongolia began joint military exercises in 2009.

An important feature of all these military exercises is that the US, Russia, China, and India all have provided and continue to provide military aid to Mongolia. While each of these countries tries to draw Mongolia into its own orbit, Mongolia has steadfastly refused to provide military a base to any of its neighbours. Yet, at the same time, Mongolia has opened up and turned itself into a military public, creating a cosmopolitical space. In other words, Mongolia has brought in all the interested military neighbours, not to target any other neighbour, but for mutual understanding. The military exercises are to enhance Mongolia's ability to contribute to global peace keeping operations, on the premise that, according to John C.K. Daly, 'collective security is the best guarantor of military protection for small states' (Daly 2008).

Today, maintaining a small army of about 10,000 troops, Mongolia does not appear to have enemies in the neighbourhood, and its national defence is predicated on global peace-keeping, not fighting any national adversary. Seven hundred years after the collapse of the Mongol Empire, Mongols have come back to build a new pax Mongolica, not through war-mongering, but through peacekeeping.

\section{Conclusion: the Centrality of Mongolia in the Assembled Neighbourhood}

The renowned world systems specialist Andre Gunder Frank (1992) once emphasized the centrality of Mongolia or Central Asia in shapingworld history. I suggest that we look at contemporary Mongolia's relations with China also in terms of a world system, rather than purely within the framework of 'international relations'. If in the past, the nomadic Huns and Mongols 
shaped the world by bursting out of the steppe and inserting themselves on other peoples through conquest, today, a tiny country is reshaping the world, albeit at a much smaller scale, perhaps even imperceptive to many. But the reassemblage of world neighbours on the Mongolian steppe shows that it is as much a working of big power competition as an active designing by the Mongols to build a world community of neighbours on the basis of sharing Mongolia's fortune-sovereignty - the heshig. It is not a Zomia, a land of refuge (Perdue 2008, Scott 2009), but its opposite, a contentious land with bursting energy.

The figure of neighbour is thus spatial and social as well as political. It is the proximity brought about by the reverse of the fortune-sovereignty that made China and the Chinese a neighbour that the Mongols have had to reckon with, and more importantly to establish their national boundary with. And similarly, like the ancient Chinese, who either cherished the men from afar (huairou yuanren 怀柔远人) or expelled the barbarians (quchu dalu/hulu 驱除鞑虏/胡虏) to maintain their 'all under heaven' (tianxia 天下), today, Mongols have also begun to engage in cosmic-moral re-ordering of the world around them, using their fortune-sovereignty.

Mongols are aware that in assembling neighbours from beyond Mongolia's immediate borders, Mongolia is actually building up a new regional polity to reduce conflict and hostility among nations in Northeast Asia. Ever conscious of history, the former Mongolian Ambassador to Japan Zamba Batjargal elaborated thus:

In $13^{\text {th }}$ and $14^{\text {th }}$ centuries, the Mongol Empire made the material and spiritual cultural exchange possible that linked the West and the East. And it created what we could call today a 'free trade zone' from Asia to Europe. It also established a political system that we could call the model of today's republican states. That time, because it implemented a generous religious and national politics among the people under its control, it was able to avert conflict and collision... The Mongolia experience shows that today big states and small states could be in equal and helpful collaboration and it [i.e., the experience] even can become an important model for the advancement of the Northeast Asian unification process. (Narangoa 2009: 377-378)

The Mongolian case shows that neighbouring does not have to be seen as a zero-sum relational game between two countries. The relational is also the organizational; in organizing or assembling a neighbourhood, Mongolia has tried to build up a cosmopolitan structure with Mongolia as the central 
node. And this is to be achieved through managing the economic interest of all the world's powers by redistributing the fortune-sovereignty, that is, Mongolia's strategic mineral resources, among them.

Note that all those who come to Mongolia uninvited or actively invited are world powers, richer, technologically more advanced, and certainly militarily more powerful than Mongolia. Mongolia has neither hard power, nor soft power to match any of these neighbours in a one to one situation. Had Mongolia followed the traditional nation-state centred approach, it would have to fight on all fronts to keep the outsiders out, but this is precisely what Mongolia is least capable of. Instead of engaging in such a futile perimeter defence, Mongolia has proactively opened up its borders, reduced its number of soldiers, and invited the world in to share Mongolia's new-found fortunesovereignty. It is in managing all these powerful neighbours, in maintaining peace among them by avoiding favouritism, or staying neutral in sharing Mongolia's fortune-sovereignty that Mongolia elevates itself above all these powers, becoming a 'big man', as it were.

In this new polity, it would serve the interest of none of the competing powers to reduce Mongolia's sovereign redistributive power. It is in everyone's interest that Mongolia remains a functional society and its political institutions are strengthened, rather than weakened. In this new Mongolia-centred world community of neighbours in the making, it is advisable that all follow the Mongolian political proverb, which says: 'deer n'suudalaa olvol, doorn' guidlee olnoo', that is, if his highness finds his seat, those below will know how to run errands. 